Article (refereed) - postprint

Bell, V.A.; Kay, A.L.; Davies, H.N.; Jones, R.G. 2016. An assessment of the possible impacts of climate change on snow and peak river flows across Britain. Climatic Change, 136 (3). 539-553. 10.1007/s10584-016-1637-x

(C) Crown Copyright 2016

This version available http://nora.nerc.ac.uk/513078/

NERC has developed NORA to enable users to access research outputs wholly or partially funded by NERC. Copyright and other rights for material on this site are retained by the rights owners. Users should read the terms and conditions of use of this material at http://nora.nerc.ac.uk/policies.html\#access

This document is the author's final manuscript version of the journal article, incorporating any revisions agreed during the peer review process. There may be differences between this and the publisher's version. You are advised to consult the publisher's version if you wish to cite from this article.

The final publication is available at Springer via http://dx.doi.org/10.1007/s10584-016-1637-x

Contact CEH NORA team at noraceh@ceh.ac.uk

The NERC and CEH trademarks and logos ('the Trademarks') are registered trademarks of NERC in the UK and other countries, and may not be used without the prior written consent of the Trademark owner. 


\title{
An assessment of the possible impacts of climate change on snow and peak river flows across Britain
}

\author{
V.A. Bell ${ }^{1}$, A.L. Kay ${ }^{1}$, H.N. Davies ${ }^{1}$ and R.G. Jones ${ }^{2}$ \\ ${ }^{1}$ Centre for Ecology \& Hydrology, Wallingford, Oxfordshire, OX10 8BB, UK \\ ${ }^{2}$ Met Office Hadley Centre, Exeter, UK \\ Corresponding author: E-mail vib@ceh.ac.uk (V.A. Bell).
}

\begin{abstract}
A temperature-based snow module has been coupled with a grid-based distributed hydrological model, to improve simulations of river flows in upland areas of Britain subject to snowfall and snowmelt. The coupled model has been driven with data from an 11-member perturbedparameter climate model ensemble, for two time-slices (1960-1990 and 2069-2099), to investigate the potential impacts of climate change. The analysis indicates large reductions in the ensemble mean of the number of lying snow days across the country. This in turn affects the seasonality of peak river flows in some parts of the country; for northerly regions, annual maxima tend to occur earlier in the water year in future. For more southerly regions the changes are less straightforward, and likely driven by changes in rainfall patterns rather than snow. The modelled percentage changes in peak flows illustrate high spatial variability in hydrological response to projected climate change, and large differences between ensemble members. When changes in projected future peak flows are compared to an estimate of current natural variability, more changes fall outside the range of natural variability in southern Britain than in the north.
\end{abstract}

\section{Keywords}

Snow, flood frequency, climate change, RCM ensemble, hydrological modelling

\section{Introduction}

The potential impacts of climate change are of increasing concern globally, and the cryosphere (snow, ice and frozen ground) may provide one of the most visible impacts, due to phase state sensitivity to temperature change (IPCC 2013, Chapter 4). There is evidence of reductions in snow cover extent in many parts of the northern hemisphere, particularly in spring (Stewart 2009), and there is some evidence that many, but not all, mountain ranges show enhanced warming with elevation (Pepin et al. 2015). Changes in snowfall have in turn affected temporal patterns of runoff and river flow in the northern hemisphere, both for catchments at high latitudes (e.g. Wilson et al. 2010) and catchments located at lower latitudes but high altitudes (e.g. López-Moreno and Garcia-Ruíz 2004). The effects strongly depend on location, and are a complex consequence of combined changes in temperature and precipitation (Stewart 2009). Projections from Global Climate Models (GCMs) suggest further reductions in snowfall and snow cover, and earlier snowmelt, in many regions in future, although a concurrent increase in precipitation in some regions leads to projected increases in winter snow accumulation (Stewart 2009). By the end of the $21^{\text {st }}$ century, more frequent occurrences of low late-season snowmelt could increase water stress, while more occurrences of high early-season snowmelt could increase flood risk (Diffenbaugh et al. 2013). However, Dankers and Feyen (2008) project decreases in the 100-year return period flood peak in parts of far north-east Europe that they link to reduced snow accumulation leading to a reduced spring runoff peak; their modelled changes for other parts of Europe were more variable.

The focus of this paper is snowmelt and flood peaks in Britain. Most of Britain does not experience sustained periods of lying snow (Dunn et al. 2001), and flow regimes in Britain are 
generally dominated by rainfall rather than snowmelt (Hannaford and Buys 2012). However, snow is a major component of flow for some catchments, particularly in Scotland (Soulsby et al. 2002), and individual snow events can affect flows anywhere in the country: snowmelt was a key factor in the major flooding that occurred across much of England in March 1947 (Booth 2007).

There have been a variety of hydrological climate change impact studies in Britain (e.g. Charlton and Arnell 2014, Cloke et al. 2013, Christierson et al. 2012, Kay and Jones 2012a, Prudhomme et al. 2012) but not all specifically discuss, or even include, the effects of snow when modelling potential changes in river flows. Exceptions include an analysis which showed increases in winter flows and decreases in spring flows in an upland catchment in northern Scotland due to changes in snow (Capell et al. 2014). The importance of including snow is specifically highlighted by Kay and Crooks (2014), who model potential future changes in annual maximum (AM) flows for 1950-2099 in three nested catchments in Scotland both with and without a snow module. When modelled with snow there were significant negative trends in 30-day AM; trends were often of the opposite sign but not significant when modelled without snow. Convergence between AM modelled with and without snow towards the end of the simulation period demonstrated the probable reduced effect of snow in future. An analysis of peak timing for a catchment in northern England showed significant negative trends in daily and 30-day AM when modelled with snow (Kay and Crooks 2014), showing that the effects of snow on flows in Britain are not limited to Scotland. A sensitivity-based approach to the impacts of climate change on flood peaks in Britain suggests that some of the more damped responses to changes in precipitation inputs are influenced by snow (Kay et al. 2014b). Both Capell et al. (2014) and Kay and Crooks (2014) highlight the complexity of the effect of snow, and changes in snow, on flows.

Previous research has used a gridded hydrological model (Grid-to-Grid; G2G) to investigate the potential impacts of climate change on flood peaks across Britain (Bell et al. 2009). However, this did not include a representation of snow accumulation and melt, the absence of which probably affected projections of the impact of climate change on flows in upland areas. This paper incorporates a simple temperature-based snow module with the G2G hydrological model. A perturbed-parameter Regional Climate Model (RCM) ensemble is then used to investigate potential future changes in snow and high flows across Britain, using G2G both with and without the snow module. The models and data are described (Section 2), and model calibration and validation presented (Section 3). Climate change impact projections are then described (Section 4), with a discussion (Section 5).

\section{Hydrological Modelling}

\subsection{The Grid-to-Grid model}

For national-scale hydrological applications, a physically-based landscape representation provides a mechanism to investigate the hydrological response of catchments to climate, landscape, or management changes. Such a representation is made possible by the availability of high resolution digital spatial datasets such as terrain, land-cover and soil information. The G2G is an area-wide distributed hydrological model which uses such spatial datasets, and was originally developed to investigate the possible impacts of climate change on flows (Bell et al. 2007, 2009). It is now routinely used for national-scale flood forecasting (Cole and Moore, 2009), for which the model's spatially-consistent understanding of area-wide response to rainfall is essential. The G2G version used here operates on a $1 \mathrm{~km}$ grid over Britain and was presented as the "Soil-G2G" in Bell et al. (2009), where further detail is provided.

The G2G generally uses spatial datasets in preference to parameter identification via calibration: the few national-scale parameters (such as the kinematic wave speeds used in lateral routing) that cannot be adequately identified from spatial data are identified using manual 
tuning to obtain satisfactory fits of simulated and observed flows across a wide range of catchments. Previous work calibrated/assessed G2G, with no snow module, for 41 catchments across Britain using daily rainfall and river flow observations (Bell et al. 2009) and for 34 catchments in the Thames Basin using 15-minute rainfall and flow (Bell et al. 2012). Assessments showed that G2G simulates river flows reasonably well, performing best for catchments with a natural flow regime (little anthropogenic influence) and a flow record that is considered accurate, but less well where the regime is influenced by artificial abstractions/discharges and where the sub-surface hydrology is unusually complex. The parameters from Bell et al. (2009) have been used here; they were identified by 'calibrating' G2G over a multi-year period, and although this period will have included some snow in some (typically higher latitude/altitude) locations it is unlikely to have greatly influenced the national-scale parameters, so the values can be considered independent of those for a snow module (see Supplementary Section 1).

\subsection{The snow module}

The introduction of a snow module into a national-scale distributed model like G2G ideally requires a method that is as simple as possible, to maintain computational and data efficiency. Temperature-index equations are commonly used for modelling snowmelt, in part because their data requirements (temperature and precipitation) are relatively modest compared to approaches that consider the full energy-balance of a snowpack (Bloschl et al. 1991). Ohmura (2001) suggests that simple temperature-index methods are often "sufficiently accurate for most practical purposes". A temperature-index approach has been adopted here as it has been shown to be effective for estimating snowmelt in British catchments subject to shallow and ephemeral snow packs (Moore et al. 1999). The purpose of the snow module is to correctly simulate the build-up and melt of a snow pack within each $1 \mathrm{~km}$ model pixel, which will introduce a delay between precipitation falling as snow and meltwater contributing to flows.

The snow module (Bell and Moore 1999) requires only precipitation and temperature data. The model partitions lying snow into 'dry' and 'wet' snow stores (Supplementary Figures 1-2). Precipitation is deemed to fall as snow when air temperature is below a threshold $T_{\text {snow }}$, and this snowfall contributes to the dry store. The wet store receives water as melt from the dry store when temperature is above a melt threshold $T_{\text {melt }}$, and the melt is calculated as a product of a melt factor $m f a c$ and the temperature difference $T-T_{\text {melt }}$. The wet store also receives water directly from rainfall (unless the dry store is empty, whereby the wet store is bypassed). Water is released from the wet store (provided $T>T_{\text {drel }}$ ) via two outlets (with rates $k_{1}$ and $k_{2}$ ), with faster release from the upper outlet occurring when the proportion of the pack that is melted snow exceeds a threshold $S_{c}$. The two wet store outputs (plus any bypassing rainfall) are combined to produce the new $1 \mathrm{~km}$ grid water input. An additional parameter, snowfac, is used as a multiplier on precipitation when it occurs as snow, to compensate for under-catch of snow by raingauges. The snow module thus operates in a grid-square only when $T<T_{\text {snow }}$ and/or there is snow in the dry or wet snow stores, and requires values for eight parameters, which are set the same for every grid-square for simplicity.

\subsection{Data}

The $\mathrm{G} 2 \mathrm{G}$ requires gridded time-series of precipitation and potential evaporation (PE), while the snow module additionally requires temperature. Observed data are used for model calibration/evaluation, and RCM data are used to assess climate change impacts.

\subsubsection{Observed climate data}

Daily precipitation data on a $5 \mathrm{~km}$ grid, provided by the Met Office for 1958-2002 (Perry et al. 2009), were used at the 15 -minute G2G time-step by equally spreading them throughout the day, and downscaled to $1 \mathrm{~km}$ using a spatial weighting based on $1 \mathrm{~km}$ Standard Average Annual Rainfall data for 1961-1990 (Bell et al. 2007). Monthly PE data on a 40km grid from MORECS (Hough and Jones 1997) were spread equally through the month and applied equally to each 
$1 \mathrm{~km}$ box within each $40 \mathrm{~km}$ square. Daily minimum and maximum temperature data on a $5 \mathrm{~km}$ grid for 1960-2006 (Perry el al. 2009) were interpolated through the day using a sine curve and downscaled to $1 \mathrm{~km}$ using a lapse rate $\left(0.0059^{\circ} \mathrm{C} / \mathrm{m}\right)$ and elevation data (Morris and Flavin 1990).

\subsubsection{Regional Climate Model data}

Data are from an 11-member perturbed-parameter GCM and RCM ensemble produced as part of UK Climate Projections 2009 (UKCP09), which provides projections specifically for use in UK impacts assessments (Murphy et al. 2009). The ensemble uses variants of the HadRM3 RCM nested within variants of the HadCM3 GCM, and the data are available on a $0.22^{\circ}$ ( $\sim 25 \mathrm{~km}$ ) rotated lat-long grid for 1950-2099, using historical emissions (up to 2000) then SRES A1B emissions (IPCC 2000) (see Bell et al. 2012 for more details). Two time-slices are usedCurrent (October 1960-September 1990) and Future (October 2069-September 2099)-each covering 30 whole water years. The G2G was run for each time-slice including a 9-month runin period (from January of the first year).

Hourly precipitation and daily minimum and maximum temperature data are directly available, and daily PE from vegetated surfaces is calculated using the method of Bell et al. (2011), which allows for leaf stomatal closure under higher atmospheric carbon dioxide concentrations; an effect that is included in six of the 11 ensemble members (Bell et al. 2012). The RCM data are downscaled in the same way as for observed data (Section 2.3.1). For further discussion on use of the RCM data for hydrological modelling, including why no bias correction is applied, see Supplementary Section 3.

Although the division of precipitation into rain and snow can be obtained directly from the $25 \mathrm{~km}$ RCM (Brown et al. 2010), using temperature to provide a partition on the $1 \mathrm{~km}$ grid allows for topographic variation within $25 \mathrm{~km}$ grid cells. However, analysis of snowfall data from the UKCP09 RCM ensemble suggests future reductions in both days of falling snow and snowfall rates, with large variations between the 11 ensemble members (Brown et al. 2010).

\section{Snow module calibration and evaluation}

A nationally-applicable snow module calibration/evaluation requires meteorological and flow data for several winter periods for which lying snow affected multiple catchments across Britain. Typically, most of the snowfall in Britain occurs on higher ground in the north and west (www.metoffice.gov.uk/learning/snow/snow-in-the-uk). Winter 1947 was one of the snowiest in the $20^{\text {th }}$ century in Britain, but pre-dates many of the national-scale weather datasets and flow measurements. Several winters affected by snow occurred in the 1960s (Bonacina snow catalogue: www.neforum2.co.uk/ferryhillweather/bonacina.html). Two of these have been used to calibrate the snow module (09/09/1961-28/05/1962 and 25/10/1962-13/05/1963), and another for evaluation (25/10/1965-13/05/1966). Of the three periods, winter 1962/1963 was most affected by snow, but each had snowfall across Britain.

A subset of 25 of the 41 catchments assessed in Bell et al. (2009) had daily flow records (National River Flow Archive: www.ceh.ac.uk/data/nrfa/) available for snow module calibration/evaluation (Supplementary Section 1). The catchments were chosen to represent a wide range of flow regimes, ranging from fast-responding upland catchments (e.g. Taw, Dee) to baseflow dominated river basins (e.g. Mimram, Lambourn).

\subsection{Calibration}

The purpose of calibration was to minimise differences between observed and modelled daily mean flows for each catchment, expressed using the $\mathrm{R}^{2}$ Efficiency as defined by Nash and Sutcliffe (1970); an $R^{2}$ of 1 indicates perfect performance while a value below 0 indicates performance worse than using mean flow. As G2G is designed for area-wide use, care has been taken not to over-calibrate to individual catchments or regions, but to maximise performance 
overall for a wide range of catchments. This approach has been continued for snow module calibration, with manual adjustment of parameters applied recursively for the two winter calibration periods to improve flow simulation across the largest possible range of snowaffected catchments. For the two calibration periods, use of the snow module leads to an increase in median $\mathrm{R}^{2}$ from 0.50 to 0.55 (winter 1961/1962) and from 0.18 to 0.56 (winter 1962/1963). The final set of parameters is in Supplementary Table 2 (note that the snowfac parameter value of 1.1 compensates for under-catch of snow by raingauges; this is set to 1.0 when RCM data are used, as they are assumed to be unaffected by under-catch).

\subsection{Evaluation}

For the evaluation period, only 13 catchments had lying snow with $>10 \mathrm{~mm}$ snow water equivalent (SWE). Performance improved for all but two of these catchments following use of the snow module, and for some northern catchments performance increased dramatically (Figure 1a). The median $\mathrm{R}^{2}$ increased from 0.50 to 0.57 following application of the snow module.

As expected, the primary benefit of using the snow module is to delay water from snow entering the soil moisture store until the temperature rises above that at which snowmelt and drainage occur. Figure $1 \mathrm{~b}-\mathrm{c}$ illustrate the improvement in modelled river flows when using the snow module for the evaluation period for two catchments; the Findhorn (07001) in Scotland and the Greta (25006) in northern England. For the Findhorn, use of the snow module increased the $\mathrm{R}^{2}$ from -0.21 to 0.28 . The observed flow peak on 7/1/1966 was simulated with the snow module on $8 / 1 / 1966$, but without the snow module two individual flow peaks were simulated shortly after the precipitation occurred. The effect of the snow module is less pronounced for the Greta, with correspondingly modest improvements in peak flow estimates though the timing is improved, leading to the $\mathrm{R}^{2}$ increasing from 0.29 to 0.51 .

Ideally, as well as evaluating the snow module via its influence on the performance of simulated river flows, evaluation would also use snow observations. However, there are a number of barriers to the success of such an evaluation, relating to availability of observed snow data and comparability of observations and modelled variables. Supplementary Section 2 presents an additional assessment of the performance of the snow module using data for the number of days of falling and lying snow and maximum snow depth for November 1965. The assessment suggests that the model estimates the number of days with falling snow reasonably well but may delay the onset of melt, causing a small overestimate of the number of days of lying snow and a corresponding overestimate of the maximum snow depth. However, comparability issues make precise statements difficult and conclusions uncertain (see Supplementary Section 2 for a discussion).

\section{Projected changes in snow and peak flows}

This section presents potential future changes in:

- number of days with lying snow;

- peak flows at two return periods (5-year and 20-year);

- dates of occurrence of annual maximum (AM) peak flows;

when modelled using RCM ensemble data for Current and Future periods (Section 2.3). The ensemble of changes in peak flows is also compared to an RCM-based estimate of current natural variability.

For the peak flow analyses, for each G2G river pixel the AM flow (and its date of occurrence) is selected from each water year ( $\left(1^{\text {st }}\right.$ October- $30^{\text {th }}$ September) of the 30 -year Current and Future simulations for each RCM ensemble member. A flood frequency curve is fitted to the $30 \mathrm{AM}$ in each set, using L-moments and the generalised logistic distribution (Robson and Reed 1999). The peak flows with return periods of 5 and 20 years are then estimated, and changes between corresponding Current and Future ensemble member pairs determined (as Bell et al. (2012)). 
Changes are generally presented as maps showing the average over the 11-member ensemble, but in some cases distributions are presented of the changes for all ensemble members and all river pixels in different regions of Britain. These regional distributions allow easier comparison of changes from Current to Future, of differences between modelling with and without snow, and of the range of results across the RCM ensemble members. In particular, distributions are used to look at changes in the date of AM occurrence, as the variability of these dates makes it less appropriate to average them.

\subsection{Change in number of days with lying snow}

Figure 2 presents maps of the mean number of days per year with lying snow, using the snow module with observed data (averaged over Oct 1961-Sep 1991) and with Current and Future RCM data (averaged over each 30-water-year time-slice and each of the $11 \mathrm{RCM}$ ensemble members). The observed and Current RCM maps are very similar, indicating that there is no significant bias introduced when using RCM data. These maps clearly show the greater number of snow days in the north than the south. The seemingly high number of snow days simulated using observed or Current RCM data is likely to be caused, at least in part, by counting every day with snow depth $>5 \mathrm{~mm}$, at any time of day (however transient), as a day of lying snow, whereas observational data generally count a day of lying snow as the presence of $>50 \%$ snow coverage at 09.00GMT (see Supplementary Section 2). Comparing the Current and Future RCM maps shows large percentage reductions in the number of snow days under climate change projections up to 2100 .

\subsection{Percentage changes in peak flows}

Figure 3 presents maps showing the ensemble mean percentage change in 5- and 20-year return period peak flows, when modelled both with and without the snow module. These show the large variation in changes across the country, but with few obvious differences when including or excluding the snow module. However, the difference maps highlight the east of Scotland and northern England, where projected increases in peak flows are often, but not always, higher if the influence of snowmelt is considered. These differences are clearer in the regional distributions (Figure 4a), illustrating the importance of including snow processes, at least for some regions. These figures also show that the changes in peak flows are generally higher in the south of the country than in the north. This is in line with spatial variation in the UKCP09 projections for the 2080s, which generally show greater increases in winter mean and extreme precipitation in the south than the north (Murphy et al. 2009 Figures 4.10 and 4.14). Further spatial differences are related to landscape properties influencing response to projected climatic changes (Kay et al. 2014a,b), with lower changes in peak flows often seen in areas of southern and eastern England underlain by chalk aquifers (as previously shown for the Thames basin, Bell et al. 2012).

To illustrate the differences across the RCM ensemble, Figure $4 \mathrm{~b}$ shows the regional mean changes in 20-year return period peak flows for each of the 11 ensemble members, superimposed on the overall regional distributions, when modelled with the snow module. The range of ensemble member means, and so the range of uncertainty from the climate model, seems to be more pronounced for regions to the south of the country, particularly the Thames and South East, than in the north.

\subsection{Changes in the dates of $\mathrm{AM}$}

Figure $4 \mathrm{c}$ presents regional summaries of the dates of AM. Comparing the AM date distributions when including or excluding the snow module confirms the importance of including snow processes in some regions of the country, with less importance in others. The eastern Scotland region shows a particular difference for the Current time-slice, with more AM flows occurring later in spring (April and May) and fewer occurring in late autumn and winter (October-February) when the snow module is included. However, for the Future time-slice 
there is much less difference between the AM date distributions when including or excluding the snow module, even in eastern Scotland, illustrating the significantly reduced influence of snow processes in a future warmer climate.

Comparing the AM date distributions with snow between the Current and Future time-slices (Figure 4c) shows changes in every region. For the more northerly regions, the tendency is for AM peaks to occur earlier in the water year, particularly to October/November in the northwest and November/December in the north-east. However, for the two most southerly regions the changes are less straightforward, with the mean date changing little but with an increase in the number of peaks occurring in November and January, little change in December, and a decrease in October and May. Southern and eastern regions of Britain tend to have lower elevations and fewer snow days than the north and west, and projected future changes in the AM dates will arise as a consequence of changes in rainfall and evaporation seasonality rather than changes in snowmelt.

Figure $4 \mathrm{c}$ also shows the mean AM dates for each RCM ensemble member, illustrating a narrower climate modelling uncertainty range for the mean dates in each region for the Future time-slice compared to the Current time-slice. The range is also narrower for more southerly regions compared to more northerly regions, in contrast to the uncertainty range for changes in 20 -year return period flow magnitudes (Figure $4 b$ ).

\subsection{Comparison with an RCM-based estimate of natural variability}

Following Bell et al (2012), an estimate of current natural variability is obtained by pooling data from a five-member subset of the 11-member RCM ensemble, carefully chosen in order to represent samples from the same population for both precipitation and PE. For each river pixel, the 30x5 AM for the Current time-slice are pooled, $30 \mathrm{AM}$ are resampled (with replacement, 200,002 times) from the pooled set, and a flood frequency curve is fitted to each set of 30 resampled AM. Percentage differences are then calculated between 100,001 pairs of resampled curves, for the 5- and 20-year return period, and the upper bound of the middle $95 \%$ of changes is found in each case (i.e. the 97.5 percentile). This bound is then used as an estimate of the threshold of current natural variability, and the number of RCM ensemble members giving percentage changes exceeding the threshold is calculated.

Maps of these natural variability exceedance counts (Figure 5) show more changes outside the range of current natural variability for the 5-year return period than the 20-year return period, and areas to the south of the country show a greater chance of exceedance than areas to the north. Areas with higher exceedance counts generally correspond with those showing greater increases in peak flows (cf. Figure 3), which are consequently more likely to exceed the range of current natural variability. There are few clear differences when modelling with or without snow, except at the lower return period for the parts of Scotland and northern England that also showed the most influence of snow on modelled peak flow changes (cf. Figure 3).

\section{Discussion and conclusions}

The evidence for warmer global air temperatures since the late $19^{\text {th }}$ century seems unequivocal (IPCC 2013, Chapter 2). These will reduce the chance of precipitation falling and lying as snow, and in turn affect temporal patterns of river flow as a consequence of combined changes in temperature and precipitation. The effect of changes in the volume and timing of snowmelt on river flows in Britain is investigated here using a national scale distributed hydrological model coupled with a snow module. Analysis of how projected future climate change might impact on snow and peak flows has used an 11-member perturbed-parameter RCM ensemble, comparing results for two time-slices (1960-1990 and 2069-2099).

When the snow module is combined with the hydrological model, the timing and magnitude of simulated river flows in areas affected by snow are generally improved, leading to an increase 
in model performance particularly in upland areas. In future, greater availability of high quality gridded observation-based hydro-meteorological datasets will enable enhancements to the melt formulation to be evaluated, including for example use of a full energy-balance in place of a temperature-only relationship. Similarly, the increasing availability of automated snow observations is likely to allow improved assessment of snowpack development and contribution of meltwater to rivers.

For projected future analyses it is especially important to include snow when looking at upland parts of Britain, as the reduced influence of snow in future periods compared to current periods could have a significant impact on flows. In fact, a recent flood attribution study for catchments in Britain suggests that the reduced chance of snowmelt floods in the present industrial climate, compared to a colder non-industrial climate, has already moderated the increased chance of autumn/winter floods due to greenhouse gas emissions (Kay et al. 2011). The analysis conducted here confirms that under a warmer climate there would be a reduction in the number of days of lying snow across the country. For the more northerly regions this leads to a tendency for peak river flows to occur earlier in the water year, either because of less snow or earlier snowmelt, but for more southerly regions the changes are less straightforward and likely to be driven by changes in rainfall rather than snow. Overall, the results highlight considerable spatial variability in fluvial response to projected climate change. There are few obvious differences when including or excluding the snow module, except in parts of eastern Scotland and northeast England. A comparison of the ensemble of changes in peak flows with an RCM-based estimate of current natural variability indicates that flow changes in more southerly regions show a greater chance of exceeding natural variability than areas to the north.

There are a number of sources of uncertainty when modelling the potential impacts of climate change on hydrological systems. The main model sources include the structure and parameterisation of the GCM, downscaling method (including RCM), and hydrological model. Other sources of uncertainty include future emissions, natural variability and PE estimation. The results presented here thus do not represent the full range of uncertainty, as only one hydrological model is applied (with one snow model) and the 11-member perturbed-parameter RCM ensemble is only available for one emissions scenario (A1B) and based on only one (perturbed-parameter) GCM (Kay and Jones 2012b). Studies have generally shown that uncertainty from climate modelling is greater than that from hydrological modelling (Kay et al. 2009, Gosling et al. 2011), although the latter can still be significant in some cases. The use of only one snow model is unlikely to be a major source of overall uncertainty, as few catchments in Britain are strongly influenced by snow. Ficklin et al. (2014) indicate that uncertainty in snowmelt model parameters can lead to statistically significant differences in hydrological climate change projections. However, Seiller and Anctil (2014) show that, for a catchment in Canada, the snow module is a much smaller source of uncertainty than hydrological model structure, PE formulation and natural variability. Studies looking at PE estimation using climate model data have shown that it can be an important source of uncertainty (Kay et al. 2013) but accounting for the influence of higher carbon dioxide concentrations on plant stomata, as here, can reduce the future PE increases that may otherwise be expected (Bell et al. 2011; Rudd and Kay 2016).

\section{Acknowledgements}

This work was undertaken under subcontract to Met Office Hadley Centre and supported by CEH National Capability Funding. RGJ acknowledges funding from the Joint DECC and Defra Met Office Hadley Centre Climate Programme (GA01101). 


\section{References}

Bell, V.A., Moore, R.J. (1999). An elevation dependent snowmelt model for upland Britain, Hydrological Processes, 13, 1887-1903.

Bell, V.A, Gedney, N., Kay, A.L., Smith, R., Jones, R.G., Moore, R.J. (2011). Estimating potential evaporation from vegetated surfaces for water management impact assessments using climate model output. J. Hydrometeorol., 12, 1127-1136.

Bell, V.A., Kay, A.L., Cole, S.J., Jones, R.G., Moore, R.J., Reynard, N.S (2012). How might climate change affect river flows across the Thames Basin? An area-wide analysis using the UKCP09 Regional Climate Model ensemble. J. Hydrol., 442-443, 89-104.

Bell, V.A., Kay, A.L., Jones, R.G., Moore, R.J. (2007). Development of a high resolution grid-based river flow model for use with regional climate model output. Hydrol. Earth Syst. Sci., 11(1), 532-549.

Bell, V.A., Kay, A.L., Jones, R.G., Moore, R.J., Reynard, N.S. (2009). Use of soil data in a grid-based hydrological model to estimate spatial variation in changing flood risk across the UK. J. Hydrol., 377(3-4), $335-350$.

Blöschl, G., Kirnbauer, R., Gutnecht, D. (1991). Distributed snowmelt simulations in an alpine catchment 1. Model evaluation on the basis of snow cover patterns Water Resour. Res., 27, 3171-3179.

Booth, G. (2007). Winter 1947 in the British Isles. Weather, 62(3), 61-68.

Brown, S., Boorman, P., Murphy, J. (2010). Interpretation and use of future snow projections from the 11 member Met Office Regional Climate Model ensemble. UKCP09 Technical note, Met Office Hadley Centre, Exeter, UK.

Capell, R., Tetzlaff, D., Essery, R., Soulsby, C. (2014). Projecting climate change impacts on stream flow regimes with tracer-aided runoff models - preliminary assessment of heterogeneity at the mesoscale. Hydrological Processes, 28(3), 545-558.

Charlton, M.B., Arnell, N.W. (2014). Assessing the impacts of climate change on river flows in England using the UKCP09 climate change projections. J. Hydrol., 519, 1723-1738.

Christierson. B.V., Vidal, J., Wade, S.D. (2012). Using UKCP09 probabilistic climate information for UK water resource planning. J. Hydrol., 424-425, 48-67.

Cloke, H.L., Wetterall, F., He, Y., Freer, J.E., Pappenberger, F. (2013). Modelling climate change impact on floods with ensemble climate projections. Q. J. R. Meteorol. Soc., 139, 282-297.

Cole, S.J., Moore, R.J. (2009). Distributed hydrological modelling using weather radar in gauged and ungauged basins. Adv. Water Resour. 32, 1107-1120.

Dankers, R., Feyen, L. (2008). Climate change impact on flood hazard in Europe: An assessment based on high-resolution climate simulations. J. Geophys. Res., 113, D19105.

Diffenbaugh, N.S., Scherer, M., Ashfaq, M. (2013). Response of snow-dependent hydrologic extremes to continued global warming. Nature Climate Change, 3, 379-384.

Dunn, S.M., Langan, S.J., Colohan, R.J.E. (2001). The impact of variable snow pack accumulation on a major Scottish water resource. Sci. Total Environ., 265, 181-194.

Ficklin, D.L., Barnhart, B.L. (2014). SWAT hydrologic model parameter uncertainty and its implications for hydroclimatic projections in snowmelt-dependent watersheds. J. Hydrol., 519, 2081-2090.

Gosling, S.N., Taylor, R.G., Arnell, N.W., Todd, M.C. (2011). A comparative analysis of projected impacts of climate change on river runoff from global and catchment-scale hydrological models. Hydrol. Earth Syst. Sci., 15, 279-294.

Hannaford, J., Buys, G. (2012). Trends in seasonal river flow regimes in the UK. J. Hydrol., 475, 158-174.

Hough, M.N., Jones, R.J.A. (1997) The United Kingdom Meteorological Office rainfall and evaporation calculation system: MORECS version 2.0-an overview, Hydrol. Earth Syst. Sci., 1, 227-239.

IPCC (2000). Special report on emissions scenarios (SRES): A special report of Working Group III of the Intergovernmental Panel on Climate Change. CUP, Cambridge, UK.

IPCC (2013). Climate Change 2013: The Physical Science Basis. Contribution of Working Group I to the Fifth Assessment Report of the Intergovernmental Panel on Climate Change [Stocker, T.F. et al. (eds.)]. CUP, Cambridge, UK.

Kay, A.L., Bell, V.A., Blyth, E.M., Crooks, S.M., Davies, H.N., Reynard, N.S. (2013). A hydrological perspective on evaporation: historical trends and future projections in Britain. Journal of Water and Climate Change, 4(3), 193-208. 
Kay, A.L., Crooks, S. (2014). An investigation of the effect of transient climate change on snowmelt, flood frequency and timing in northern Britain. Int. J. Clim., 34, 3368-3381.

Kay, A.L., Crooks, S.M., Davies, H.N., Prudhomme, C., Reynard, N.S. (2014a). Probabilistic impacts of climate change on flood frequency using response surfaces. I: England and Wales. Regional Environmental Change, 14(3), 1215-1227.

Kay, A.L., Crooks, S.M., Davies, H.N., Reynard, N.S. (2014b). Probabilistic impacts of climate change on flood frequency using response surfaces. II: Scotland. Regional Environmental Change, 14(3), 1243-1255.

Kay, A.L., Crooks, S.M., Pall, P., Stone, D. (2011). Attribution of Autumn/Winter 2000 flood risk in England to anthropogenic climate change: A catchment-based study. J. Hydrol., 406, 97-112.

Kay, A.L., Davies, H.N., Bell, V.A., Jones, R.G. (2009). Comparison of uncertainty sources for climate change impacts: flood frequency in England. Climatic Change, 92(1-2), 41-63.

Kay, A.L., Jones, D.A. (2012a). Transient changes in flood frequency and timing in Britain under potential projections of climate change. Int. J. Clim., 32(4), 489-502.

Kay, A.L., Jones, R.G. (2012b). Comparison of the use of alternative UKCP09 products for modelling the impacts of climate change on flood frequency. Climatic Change, 114(2), 211-230.

López-Moreno, J.I., Garcia-Ruíz, J.M. (2004). Influence of snow accumulation and snowmelt on streamflow in the central Spanish Pyrenees. Hydrological Sciences Journal, 49, 787-802.

Moore, R.J., Bell, V.A., Austin, R.M., Harding, R.J. (1999) Methods for snowmelt forecasting in upland Britain. Hydrol. Earth Syst. Sci., 3(2), 233-246.

Morris, D.G., Flavin, R.W. (1990). A digital terrain model for hydrology. In: Proceedings of the 4th International Symposium on Spatial Data Handling, Zurich, Switzerland, 23 -27 July 1990, 1, 250-262.

Murphy, J.M., Sexton, D.M.H., Jenkins, G.J. et al. (2009). UK Climate Projections Science Report: Climate Change Projections. Met Office Hadley Centre, Exeter.

Nash, J.E., Sutcliffe, J.V. (1970). River flow forecasting through conceptual models. Part I: A discussion of principles. J. Hydrol. 10(3), 282-290.

Ohmura, A. (2001). Physical basis for the temperature-based melt-index method. J. Appl. Meteor., 40, $753-$ 761.

Pepin, N. et al. (2015). Elevation-dependent warming in mountain regions of the world. Nature Climate Change 5, 424-430.

Perry M., Hollis D., Elms M. (2009). The generation of daily gridded datasets of temperature and rainfall for the UK, Climate Memorandum No.24, National Climate Information Centre, Met Office, Exeter, UK.

Prudhomme, C., Young, A., Watts, G. et al. (2012). The drying up of Britain? A national estimate of changes in seasonal river flows from 11 Regional Climate Model simulations. Hydrological Processes, 26, 1115-1118.

Robson, A.J., Reed, D.W. (1999). Statistical procedures for flood frequency estimation. Vol. 3, Flood Estimation Handbook. Institute of Hydrology, Wallingford, UK.

Rudd, A.C., Kay, A.L. (2015). Use of very high resolution climate model data for hydrological modelling: estimation of potential evaporation. Hydrology Research, doi:10.2166/nh.2015.028.

Seiller, G., Anctil, F. (2014). Climate change impacts on the hydrologic regime of a Canadian river: comparing uncertainties arising from climate natural variability and lumped hydrological model structures. Hydrol. Earth Syst. Sci., 18, 2033-2047.

Soulsby, C., Black, A.R., Werritty. A. (2002). Hydrology in Scotland: towards a scientific basis for the sustainable management of freshwater resources - foreword to the thematic issue. Sci. Total Environ., 294, $3-11$.

Stewart, I.T. (2009). Changes in snowpack and snowmelt runoff for key mountain regions. Hydrological Processes, 23, 78-94.

Wilson, D., Hisdal, H., Lawrence, D. (2010). Has streamflow changed in the Nordic countries? Recent trends and comparisons to hydrological projections. J. Hydrol., 394, 334-346. 


\section{Figures}

(a) $R^{2}$ values for 13 catchments

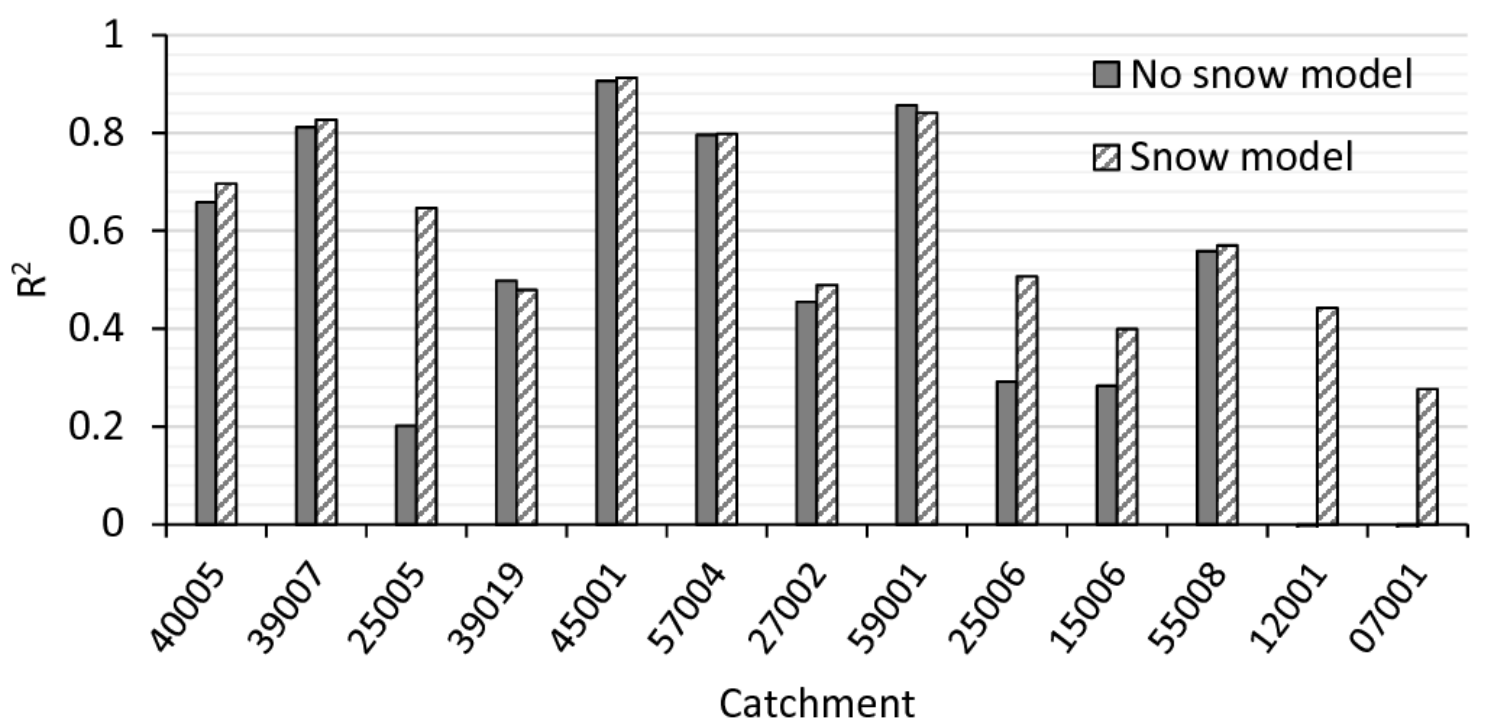

(b) Findhorn (07001)
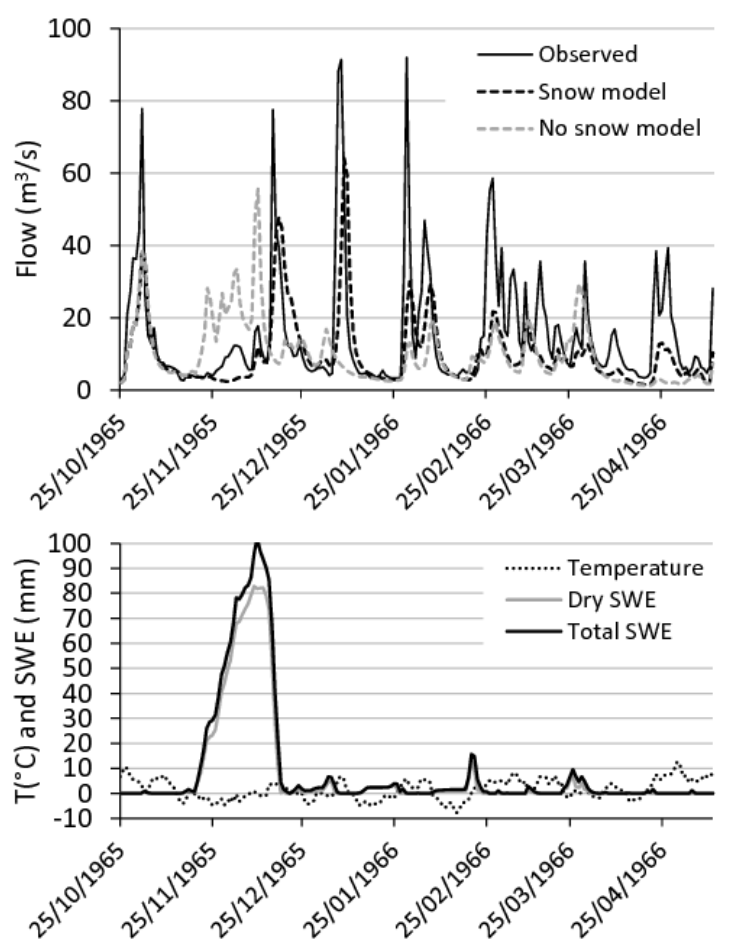

(c) Greta (25006)
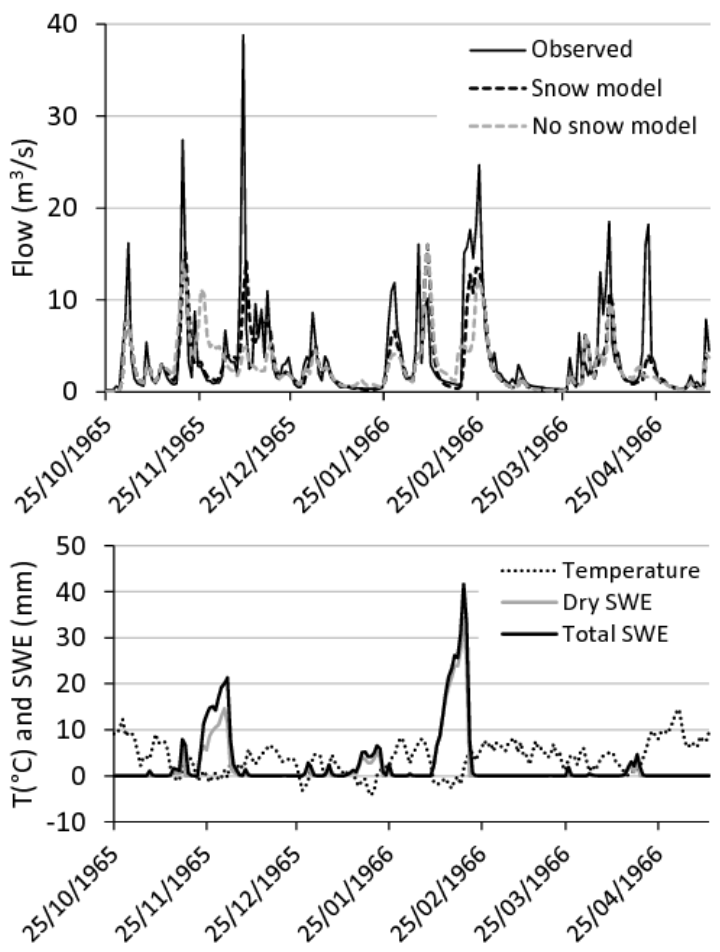

Figure 1 (a) Change in $R^{2}$ on implementation of the snow module (25/10/1965-13/05/1966) for 13 catchments, ranked (from left) in order of increasing mean catchment elevation (where no $\mathbf{R}^{2}$ is plotted with no snow module, it was negative): (b) Flow hydrographs and corresponding SWE and daily mean temperature at the gauging station for the Findhorn: (c) as (b) but for the Greta. 


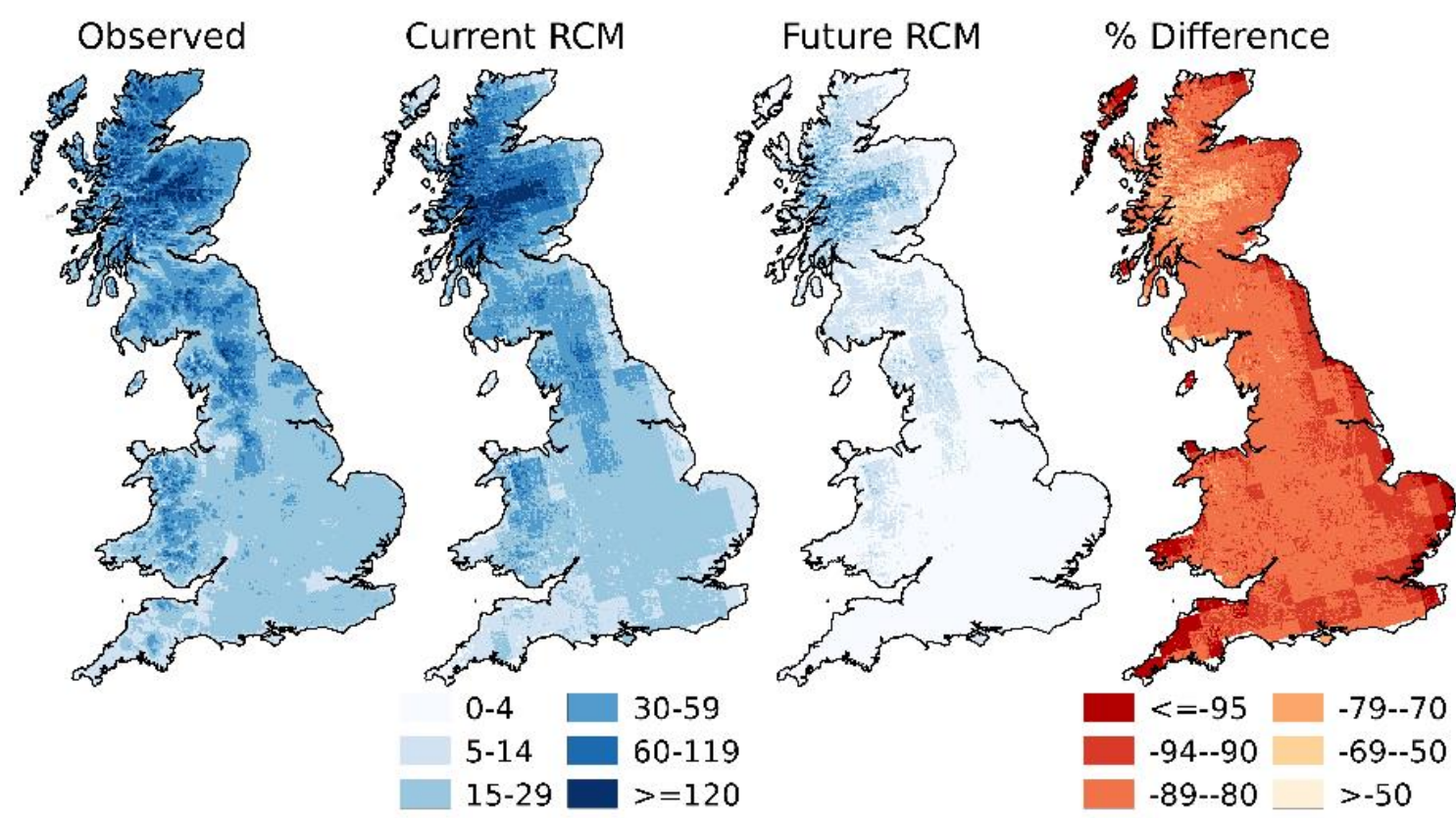

Figure 2 Maps showing the mean number of days per year with lying snow, using the snow module with observed data (averaged over water years 1961-1991; left) and with Current and Future RCM data (averaged over the RCM ensemble and each 30-water-year timeslice). Also shown is the percentage change from Current to Future (right). 


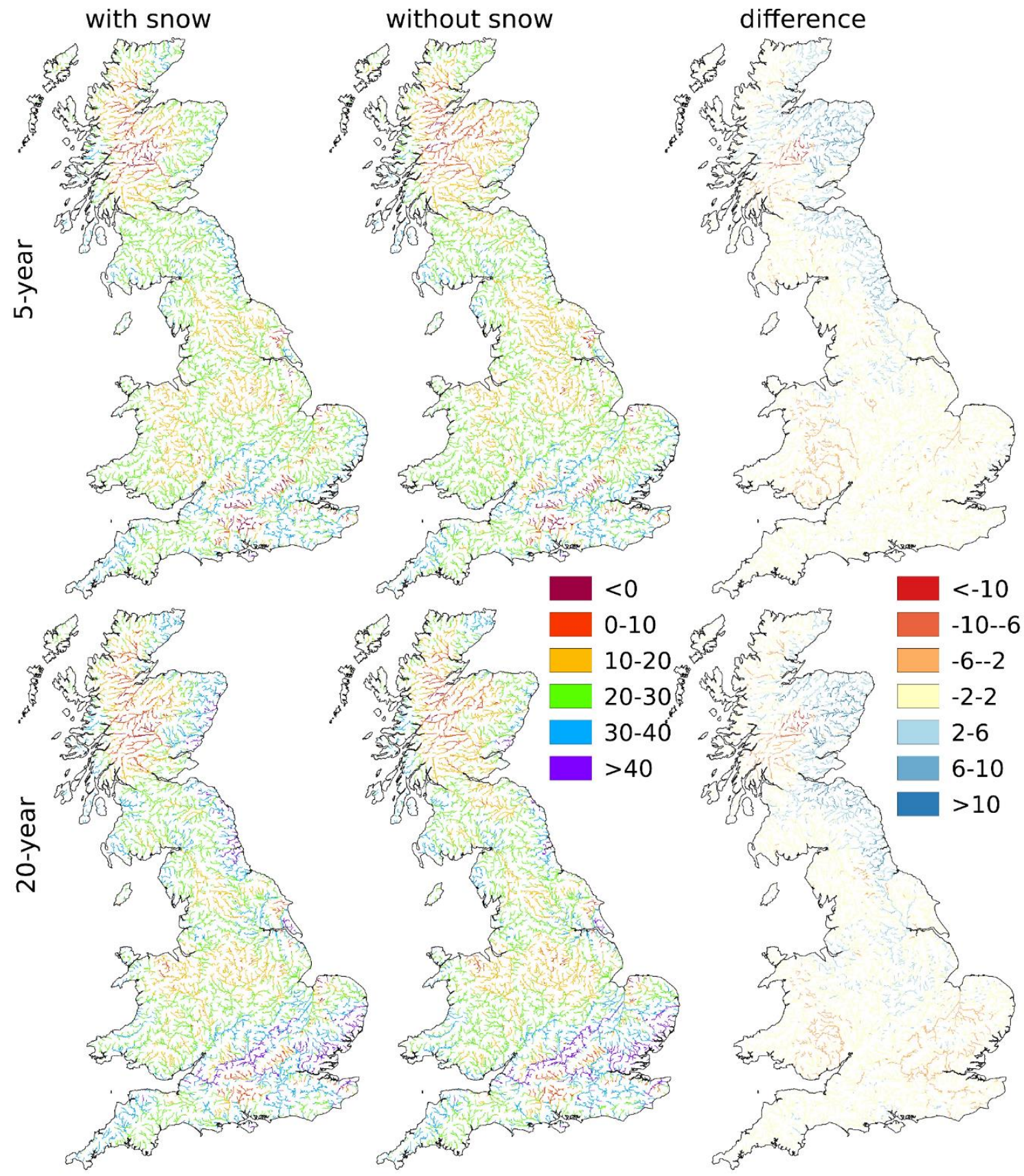

Figure 3 The ensemble mean percentage change in peak flows at 5- and 20-year return periods, modelled both with the snow module (left) and without (middle), and the difference ('with snow' minus 'without snow'; right). 
(a)
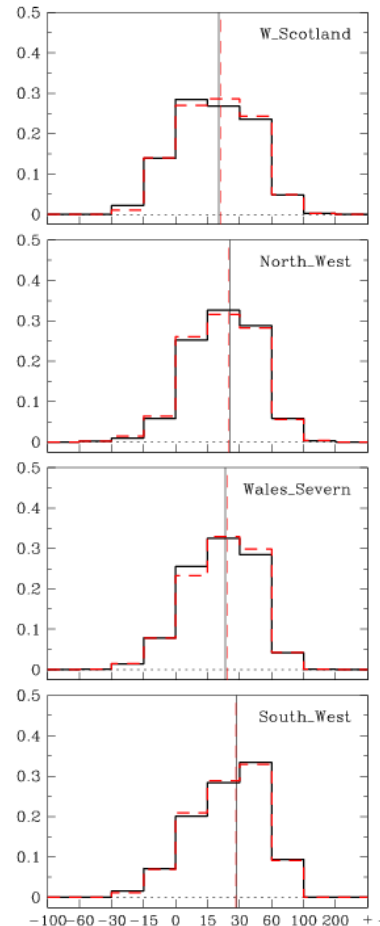

(c)
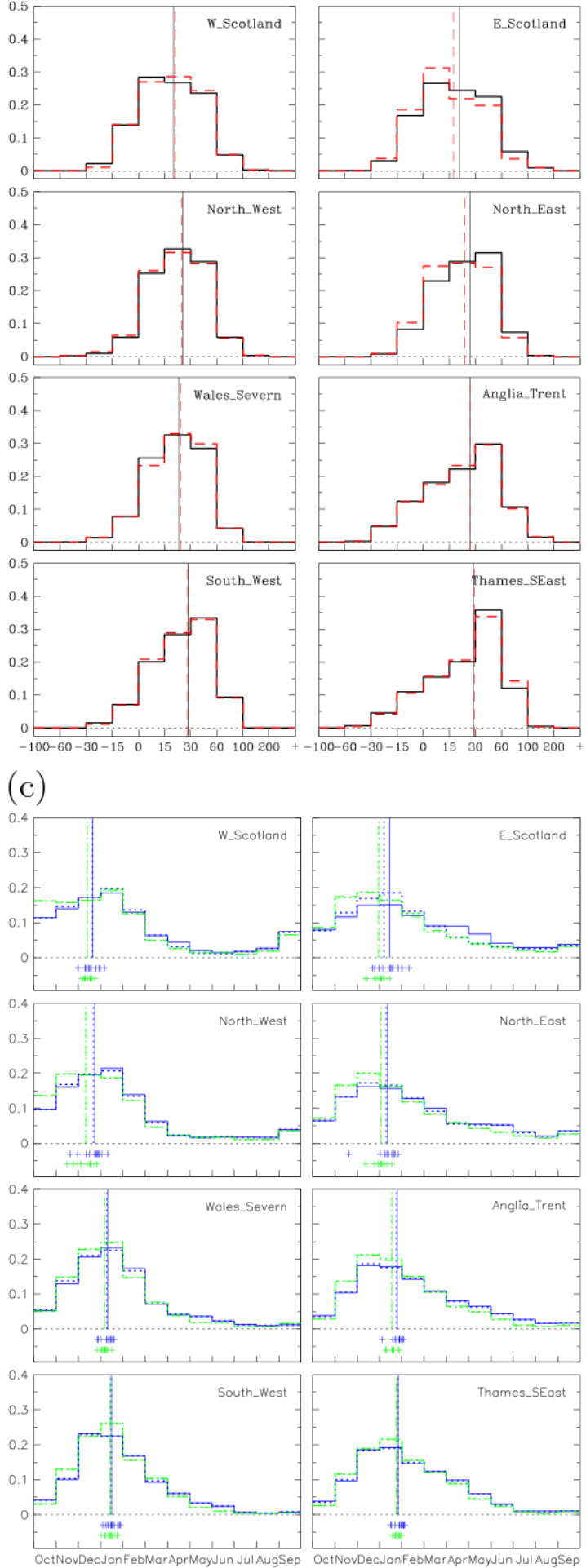

(b)
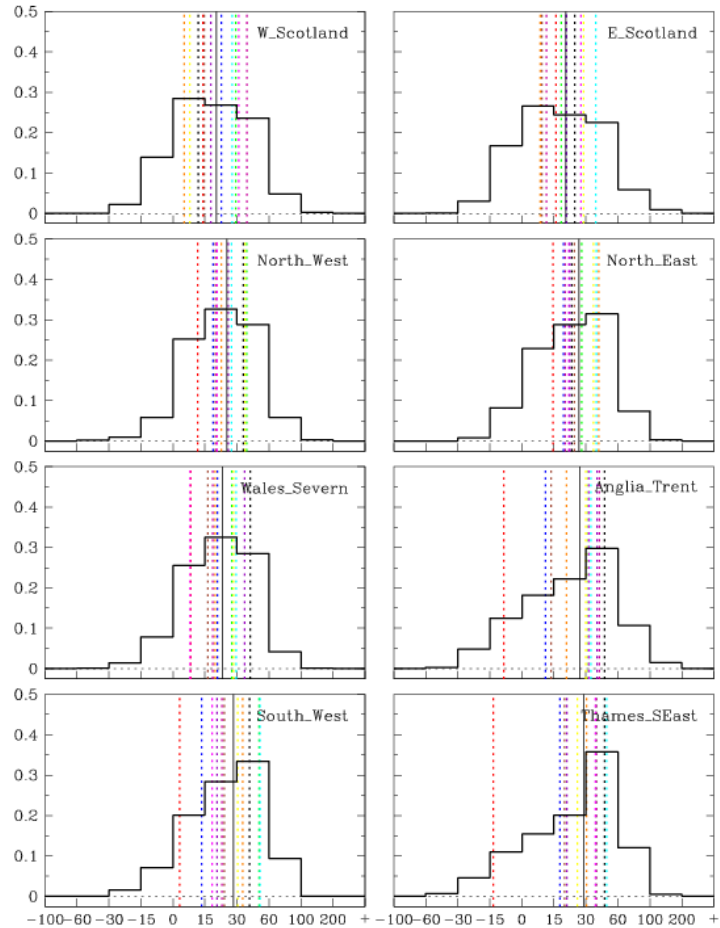

(d)

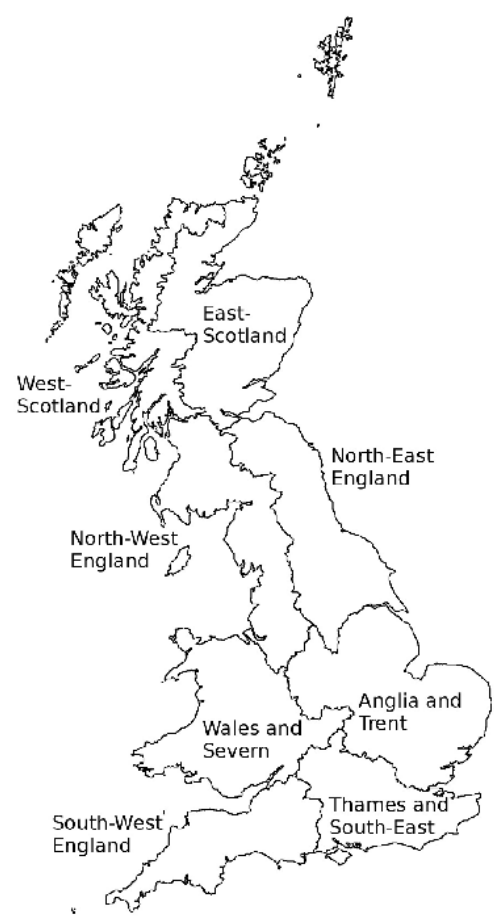

Figure 4 Regional summaries of RCM ensemble results. (a) Percentage changes in 20-year return period peak flows, as distributions (histograms) and means (vertical lines) both with the snow module (black solid) and without (red dashed): (b) Percentage changes in 20-year return period peak flows, as distributions with the snow module (black histograms) with the means for each RCM ensemble member (dotted vertical lines). (c) Dates of occurrence of AM flows, as distributions for the Current (blue) and Future (green) time-slices, both with the snow module (solid or dashed) and without (dotted). The overall means are shown by corresponding vertical lines, with means for each ensemble member (with snow) shown by plus signs below the zero $y$-axis. The regions are arranged approximately geographically in (a)-(c); see map (d). Note the nonlinear $x$-axes in (a)-(b). 

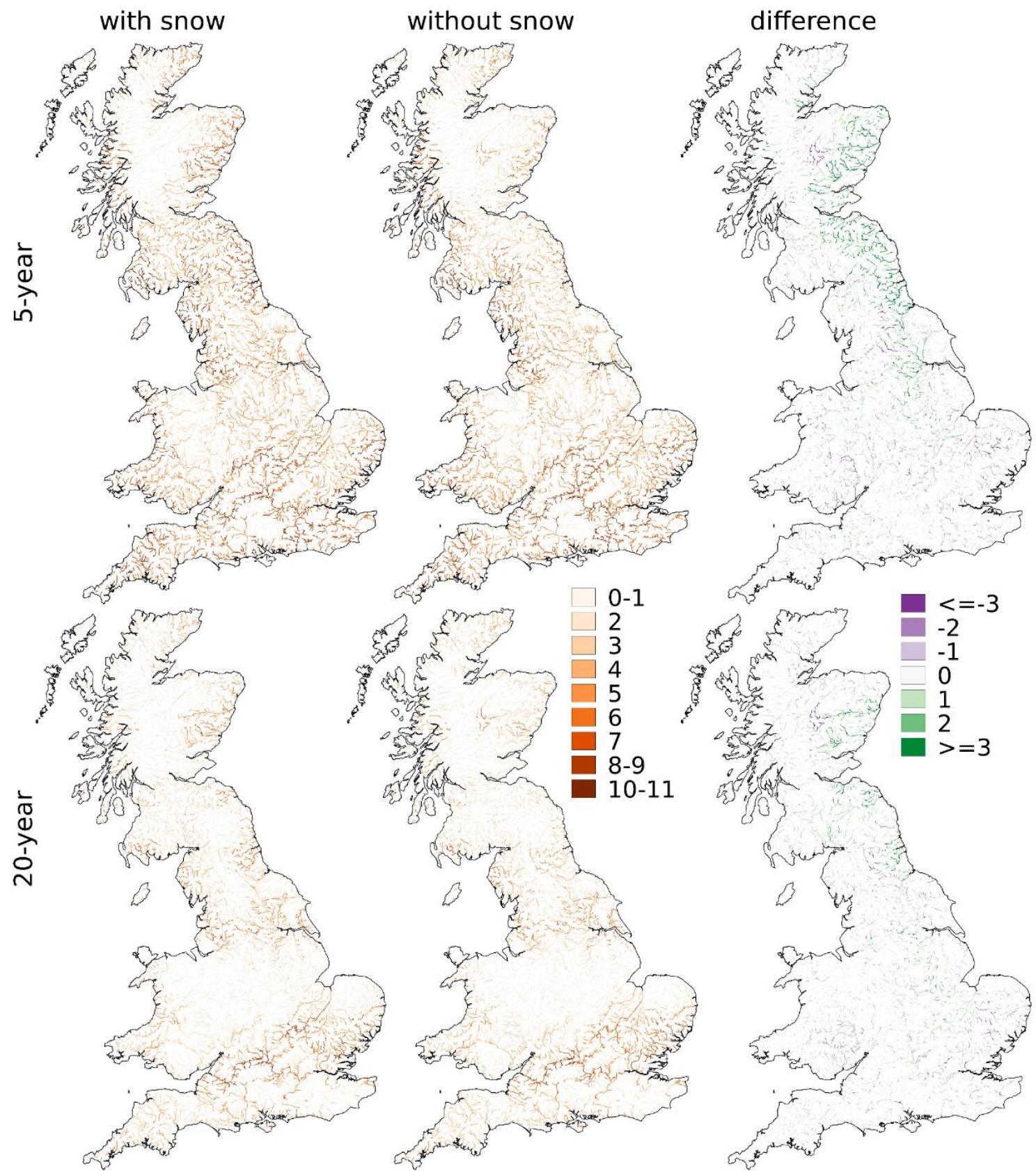

Figure 5 The number of RCM ensemble members for which the change in peak flows is above the upper $95 \%$ natural variability bound, for peak flows at 5-and 20-year return periods, modelled both with the snow module (left) and without (middle). Also shown is the difference ('with snow' minus 'without snow'; right). 


\section{Supplementary Material}

\section{The snow module and its calibration}

The G2G hydrological model was configured to use spatial landscape information contained in gridded physically-based datasets as much as possible, leaving little in the way of traditional calibration for the user to undertake. Typically, any calibration that is undertaken is not restricted to individual catchments as parameter values are applied nationally (Bell et al. 2009). Thus G2G 'calibration' involves manual tuning of a small number of national-scale parameter values (such as the kinematic wave speed used in lateral routing), to obtain satisfactory fits of simulated and observed flows across a wide-range of catchments for a short but multi-year predominantly snow-free period.

Figure 1 presents a schematic of the snow module, with a flow diagram in Figure 2. For calibration of the snow module, the existing G2G hydrological parameterisation is retained as the nature and design of the G2G model (i.e. few national-scale parameter to tune) and its calibration process (i.e. use of a multi-year predominantly snow-free period, and assessment of performance by inspecting flow hydrographs as well as $\mathrm{R}^{2}$ values, so any potential influence of snow on higher altitude/latitude catchments could be borne in mind) ensure that the parameters will not have been significantly influenced by snow so can be considered independent of those for a snow module.

Snow module calibration concentrated on specific large-scale snow periods (09/09/1961$28 / 05 / 1962$ and 25/10/1962-13/05/1963) using a subset of 25 of the 41 catchments used in the original G2G calibration (the others do not have daily flow observations available for these periods). The catchments used for calibration of the snow module with G2G are mapped in Figure 3 and listed in Table 1. The final snow module parameters are given in Table 2. Decoupling the G2G hydrological model and snow module calibrations in this way (using a multiyear predominantly snow-free period for hydrological model 'calibration' then specific snowy periods for 'calibrating' the snow module parameters alone) is likely to lead to more robust parameter values for both; attempting to calibrate both sets of parameters simultaneously would be more likely to lead to problems identifying optimum values due to potential compensatory effects.

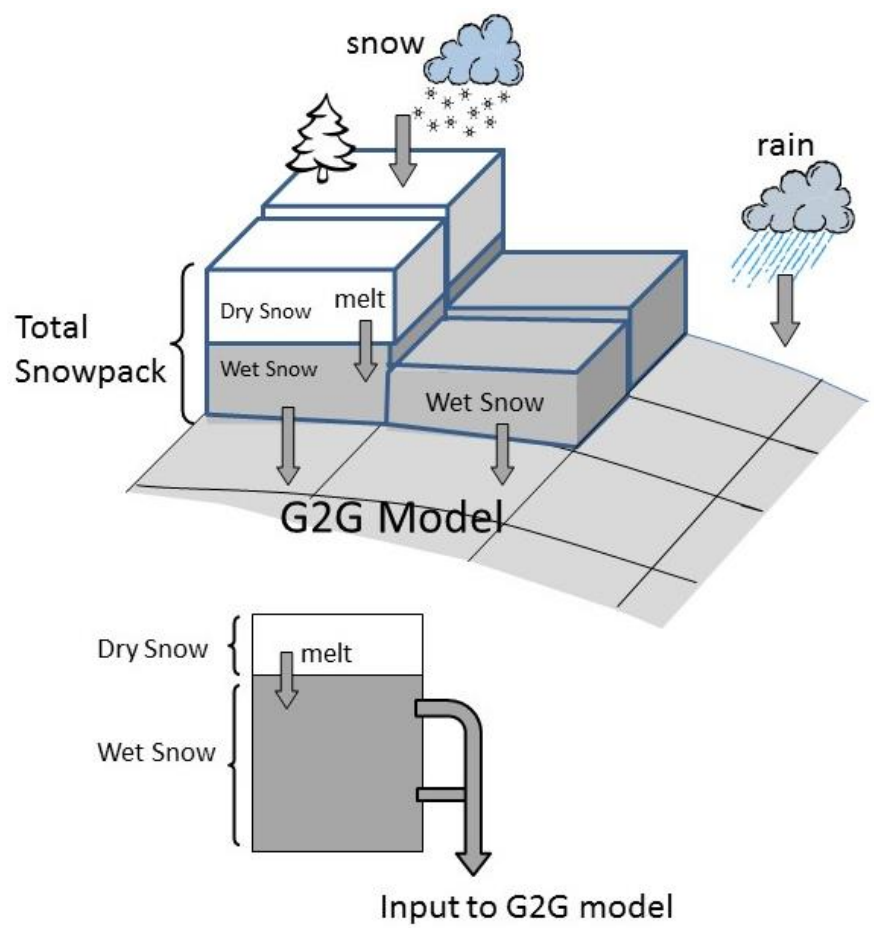

Figure 1 Schematic showing key processes in the snow module. 


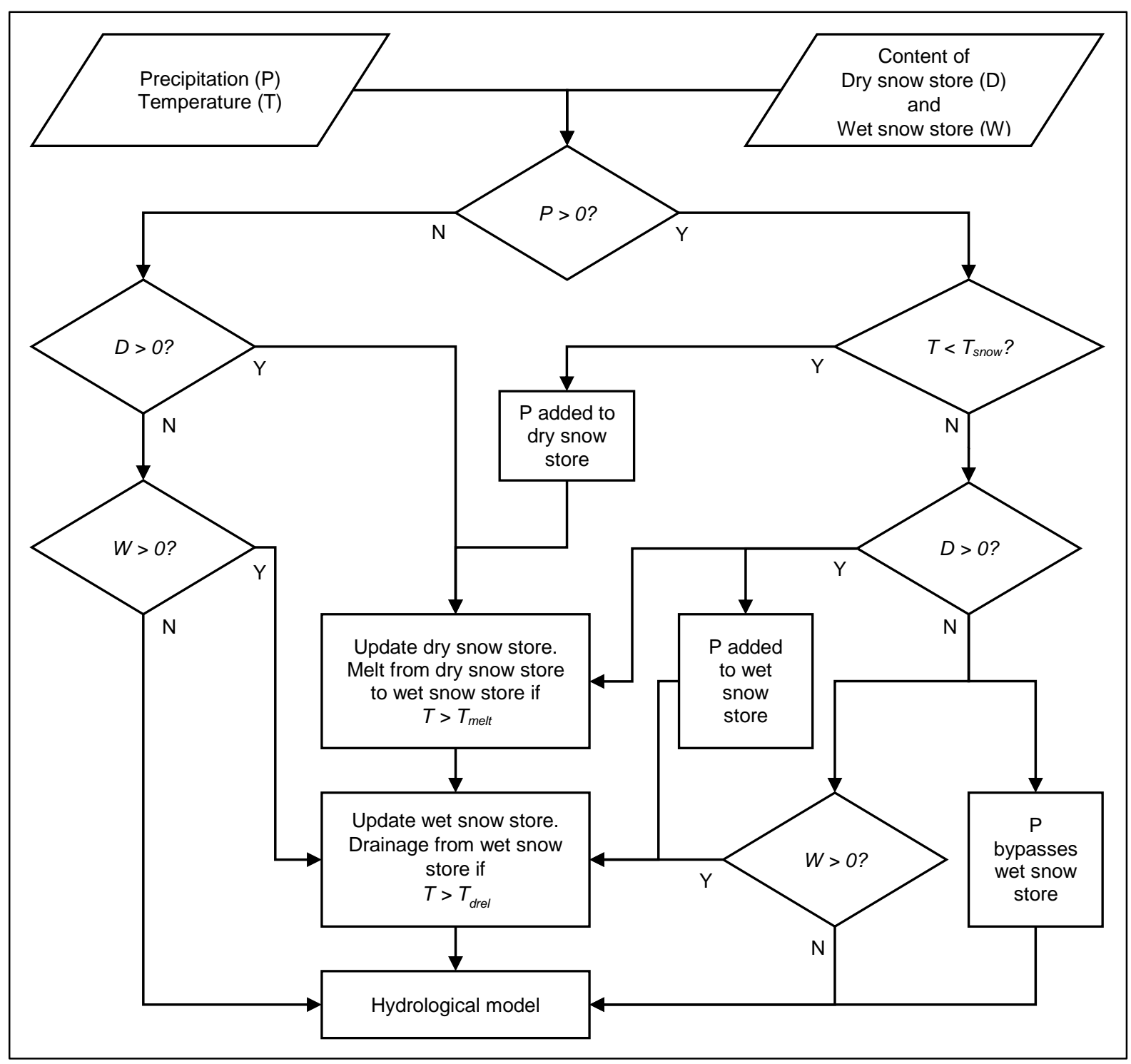

Figure 2. Snow module flow diagram, showing the process for each time-step (see Table 2 for definitions of $T_{\text {snow }}, T_{m e l t}$ and $T_{\text {drel }}$ ). 


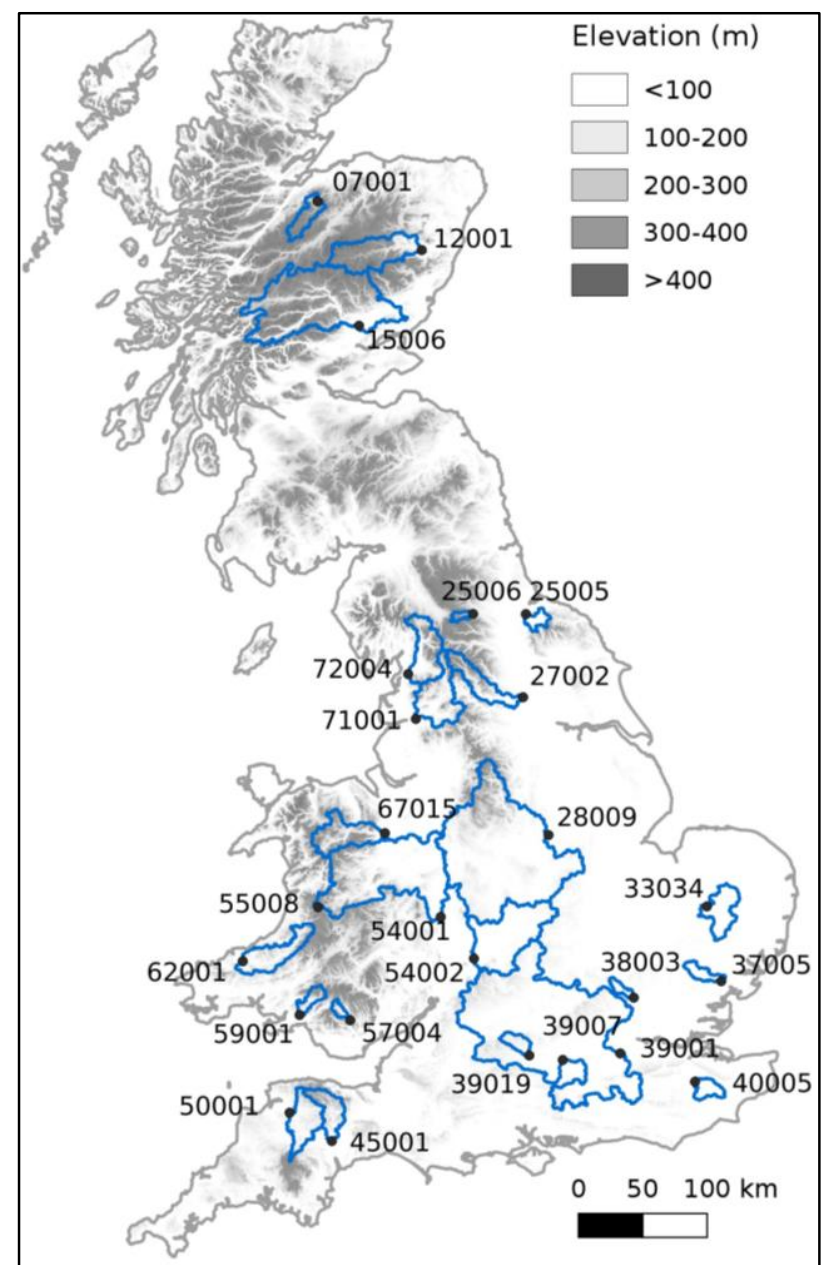

Figure 3 Map showing the 25 catchments used for calibration of the snow module, with catchment IDs, drainage outlets and underlying elevation $(\mathbf{m})$.

Table 1 The 25 catchments used for calibration of the snow module.

\begin{tabular}{|c|c|c|c|c|c|}
\hline Catchment name & ID & $\begin{array}{l}\text { Area } \\
\left(\mathrm{km}^{2}\right)\end{array}$ & $\begin{array}{c}\text { Minimum } \\
\text { elevation }(\mathrm{m})\end{array}$ & $\begin{array}{c}\text { Maximum } \\
\text { elevation }(\mathrm{m})\end{array}$ & $\begin{array}{c}\text { Mean } \\
\text { elevation }(\mathrm{m})\end{array}$ \\
\hline Findhorn at Shenachie & 07001 & 416 & 252 & 933 & 560 \\
\hline Dee at Woodend & 12001 & 1370 & 72 & 1309 & 512 \\
\hline Tay at Ballathie & 15006 & 4587 & 22 & 1210 & 411 \\
\hline Leven at Leven Bridge & 25005 & 196 & 3 & 452 & 126 \\
\hline Greta at Rutherford Bridge & 25006 & 86 & 222 & 588 & 402 \\
\hline Wharfe at Flint Mill Weir & 27002 & 759 & 12 & 703 & 273 \\
\hline Trent at Colwick & 28009 & 7486 & 20 & 636 & 142 \\
\hline Lt. Ouse at Abbey Heath & 33034 & 688 & 8 & 95 & 42 \\
\hline Colne at Lexden & 37005 & 238 & 10 & 113 & 66 \\
\hline Mimram at Panshanger Pk & 38003 & 134 & 48 & 194 & 121 \\
\hline Thames at Kingston & 39001 & 9948 & 4 & 330 & 109 \\
\hline Blackwater at Swallowfield & 39007 & 355 & 43 & 224 & 88 \\
\hline Lambourn at Shaw & 39019 & 234 & 73 & 260 & 164 \\
\hline Beult at Stile Bridge & 40005 & 277 & 13 & 161 & 44 \\
\hline Exe at Thorverton & 45001 & 601 & 28 & 512 & 244 \\
\hline Taw at Umberleigh & 50001 & 826 & 11 & 811 & 182 \\
\hline Severn at Bewdley & 54001 & 4325 & 19 & 826 & 175 \\
\hline Avon at Evesham & 54002 & 2210 & 21 & 316 & 99 \\
\hline Wye at Cefn Brwyn & 55008 & 11 & 345 & 737 & 495 \\
\hline Cynon at Abercynon & 57004 & 106 & 82 & 516 & 271 \\
\hline Tawe at Ynystanglws & 59001 & 228 & 12 & 801 & 287 \\
\hline Teifi at Glan Teifi & 62001 & 894 & 4 & 591 & 209 \\
\hline Dee at Manley Hall & 67015 & 1019 & 28 & 878 & 339 \\
\hline Ribble at Samlesbury & 71001 & 1145 & 8 & 688 & 221 \\
\hline Lune at Caton & 72004 & 983 & 12 & 734 & 275 \\
\hline
\end{tabular}


Table 2 Snow module parameters and their calibrated values.

\begin{tabular}{lllr}
\hline Parameter & Description & Units & Calibrated value \\
\hline snowfac & Precipitation factor & dimensionless & 1.1 \\
$T_{\text {snow }}$ & Temperature below which precipitation is snow & ${ }^{\circ} \mathrm{C}$ & 0.0 \\
$T_{\text {melt }}$ & Temperature above which melt occurs & ${ }^{\circ} \mathrm{C}$ & 1.0 \\
$T_{\text {drel }}$ & Temperature below which no drainage occurs & ${ }^{\circ} \mathrm{C}$ & 0.0 \\
$m f a c$ & Melt factor & $\mathrm{mm} /$ day $/{ }^{\circ} \mathrm{C}$ & 7.0 \\
$k_{1}$ & Storage time constant: lower outlet & day $^{-1}$ & 0.5 \\
$k_{2}$ & Storage time constant: upper outlet & day $^{-1}$ & 0.9 \\
$S_{c}$ & Maximum proportion of liquid water content & dimensionless & 0.18 \\
\hline
\end{tabular}

\section{Evaluation against snow data}

Historically, measurements of snowfall, snow depth and snow water equivalent (SWE; the depth of water when the snow has melted) have been limited by the requirement for a manual observer to obtain them. One national source of historical snow data is the Snow Survey of Great Britain (SSGB), for which the Met Office provides reports covering approximately 100 stations with monthly data for the number of days with snow falling, lying and maximum snow depth for 1953-1992 (www.metoffice.gov.uk/learning/library/archive-hidden-treasures/snowsurvey). As an additional assessment of the performance of the snow module, data for November 1965 (Booth, 1966) have been digitised and mapped to station locations. Additional data for Scotland are now available digitally (Spencer et al. 2014), but have not been used here.

Figure 4 compares G2G output for November 1965 with the above observations of number of days of falling and lying snow and maximum snow depth. Results suggest that, although the module estimates the number of days with falling snow reasonably well (mean underestimate of 2 days), it appears to delay the onset of melt, causing an overestimate of the number of days of lying snow (mean 2-3 days) and a corresponding overestimate of the maximum snow-depth (mean $5 \mathrm{~cm}$ ). However, it is important to note that there will be a high degree of uncertainty in comparing an observed snow record at a single location and a model estimate for a $1 \mathrm{~km}$ square. Point snow measurements can be unrepresentative of snow over wider areas (Grunewald and Lehning 2015), and the precise definition of a variable can also be critical. For example, the SSGB data for the 'number of days of lying snow' is actually a count of the days with 'half or more of the ground in the immediate neighbourhood snow-covered', which is both potentially subjective (in terms of the observer taking the measurements) and difficult to translate into a comparable measure valid over a $1 \mathrm{~km}$ model grid square. Furthermore, the SSGB data on lying snow and snow depth apply at '09 GMT or thereabouts' but the model only has daily total precipitation and daily minimum and maximum temperature, making comparison of model outputs at a precise time during the day unwise. The model estimates of lying snow thus count the number of days with over $5 \mathrm{~mm}$ snow depth at any time of day (regardless of transience), thus are likely to overestimate compared to observations. Similarly, the modelled maximum depth is taken from any time of day and so is likely to be an overestimate. 
(a) Days of falling snow
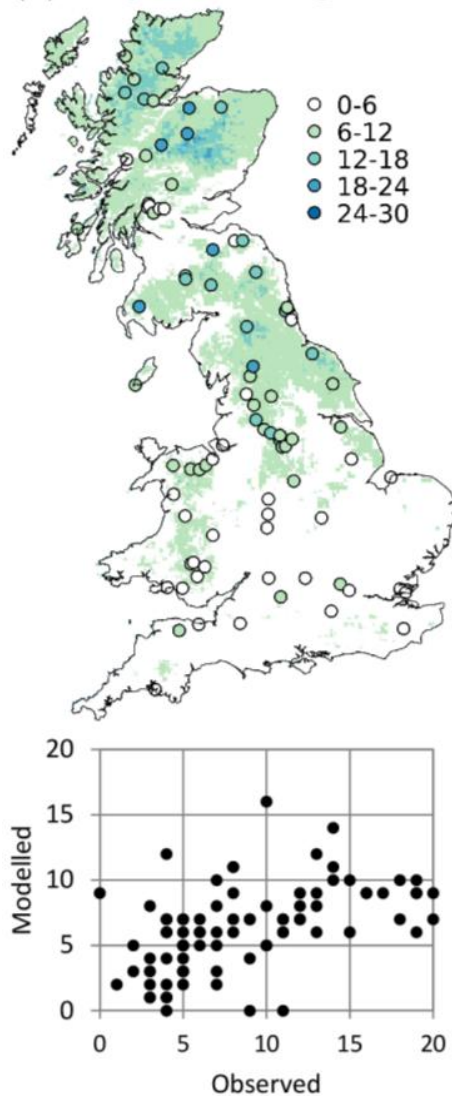

(b) Days of lying snow
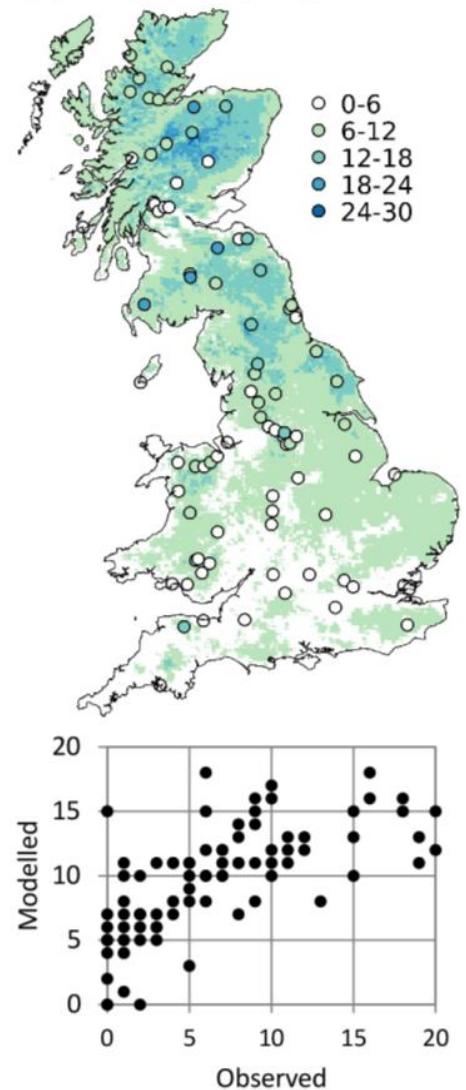

(c) Maximum snow depth
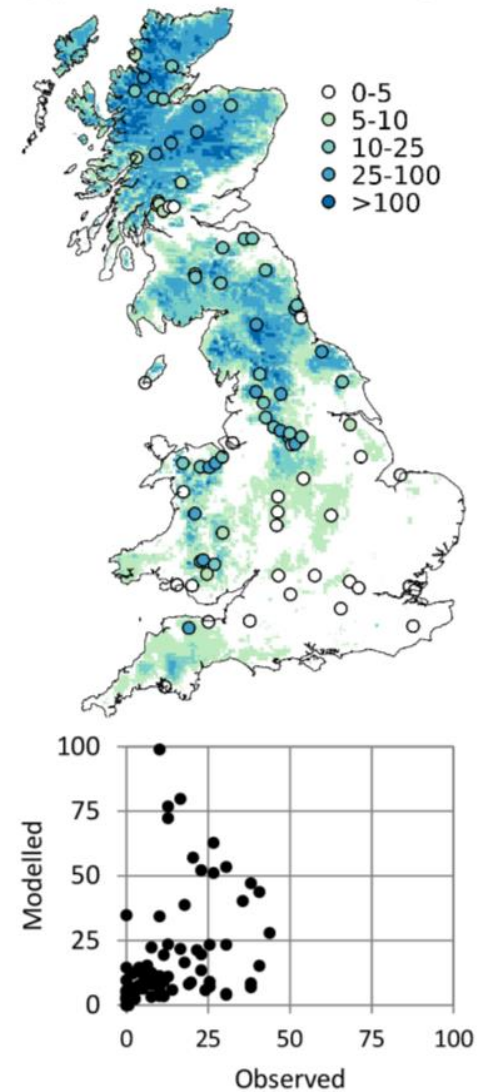

Figure 4 Comparison of observed and modelled number of days with snowfall and lying snow, and maximum snow depth (cm) for sites across Britain, November 1965.

\section{Use of RCM data}

The RCM data used in the study were made available as part of UKCP09, which has been widely used to assess impacts of climate change over the UK. The main messages on climate change over the UK from this set of CMIP3 outputs are little different from those arising from the more recent CMIP5 (see for example McSweeney and Jones (2013) Figure 4). Also, the UKCP09 projections, by design, incorporate the range of uncertainty within CMIP3, and the changes in the full UKCP09 projections have been compared with those from the 11 RCMs in Kay and Jones (2012b).

A comparison of monthly mean rainfall and PE data from the Current RCM ensemble (19611990) with observation-based estimates for the Thames shows relatively good performance (Bell et al. 2012). Also, Smith et al. (2014) assess precipitation, for four catchments in Britain, produced using the 11-member UKCP09 RCM ensemble along with 8 RCM runs from ENSEMBLES. They show that the RCMs have some skill in simulating both monthly mean precipitation and seasonal extreme n-day precipitation totals, and state that 'using an ensemble mean generated from multiple RCMs produces more accurate results than using individual RCM output'.

Climate model data generally require some form of downscaling, especially for precipitation, before use by hydrological models. Downscaling is sometimes combined with bias correction (e.g. Prudhomme et al. 2012), however several recent papers have cast doubt on the assumption that bias correction improves the reliability of results from subsequent hydrological modelling (Addor and Seibert 2014, Huang et al. 2014, Ehret et al. 2012). Cloke et al. (2013) discuss some of the assumptions inherent in bias correction (e.g. stationarity of biases) and state 'there remains an open question as to whether or not MOS [bias correction] should be applied in 
impact modelling'. Separate bias correction of different variables can also introduce inconsistencies, which could cause problems for the estimation of potential evaporation (Kay et al. 2013), as well as for snow modelling.

Several previous studies have used the UKCP09 RCM ensemble data for hydrological modelling of catchments in Britain without bias correction (Bell et al. 2012; Kay and Jones 2012a,b; Cloke et al. 2013; Kay and Crooks 2014). A comparison of observed flood frequency curves with those simulated for four sub-catchments of the Thames using $\mathrm{G} 2 \mathrm{G}$ shows relatively good performance (Bell et al. 2012), as does a similar comparison for nine catchments in Britain simulated using the Probability Distributed Model (Kay and Jones 2012b). Bias correction is thus not applied here, as the RCM data are relatively good for Britain, there are doubts over the usefulness of bias correction, and the analyses focus on changes between Current and Future periods and on ensemble means.

\section{References}

Addor, N., Seibert, J. (2014). Bias correction for hydrological impact studies - beyond the daily perspective. Hydrological Processes, 28, 4823-4828.

Bell, V.A., Kay, A.L., Cole, S.J., Jones, R.G., Moore, R.J., Reynard, N.S (2012). How might climate change affect river flows across the Thames Basin? An area-wide analysis using the UKCP09 Regional Climate Model ensemble. J. Hydrol., 442-443, 89-104.

Bell, V.A., Kay, A.L., Jones, R.G., Moore, R.J., Reynard, N.S. (2009). Use of soil data in a grid-based hydrological model to estimate spatial variation in changing flood risk across the UK. J. Hydrol., 377(3-4), 335-350.

Booth, R.E. (1966). Snow Survey of Great Britain 1965-66. Meteorological Office, Her Majesty’s Stationery Office, 1966.

Cloke, H.L., Wetterhall, F., He, Y., Freer, J.E., Pappenberger, F. (2013). Modelling climate impact on floods with ensemble climate projections. Quarterly Journal of the Royal Meteorological Society, 139, 282-297.

Ehret, U., Zehe, E., Wulfmeyer, V. et al. (2012). Should we apply bias correction to global and regional climate model data? Hydrology and Earth System Sciences, 16, 3391-3404.

Grunewald, T., Lehning, M. (2015). Are flat-field snow depth measurements representative? A comparison of selected index sites with areal snow depth measurements at the small catchment scale. Hydrological Processes, 29, 1717-1728.

Huang, S., Krysanova, V., Hatterman, F.F. (2014). Does bias correction increase reliability of flood projections under climate change? A case study of large rivers in Germany. International Journal of Climatology, 34, 3780 3800 .

Kay, A.L., Bell, V.A., Blyth, E.M., Crooks, S.M., Davies, H.N., Reynard, N.S. (2013). A hydrological perspective on evaporation: historical trends and future projections in Britain. Journal of Water and Climate Change, 4(3), 193-208.

Kay, A.L., Crooks, S. (2014). An investigation of the effect of transient climate change on snowmelt, flood frequency and timing in northern Britain. Int. J. Clim., 34, 3368-3381.

Kay, A.L., Jones, D.A. (2012a). Transient changes in flood frequency and timing in Britain under potential projections of climate change. Int. J. Clim., 32(4), 489-502.

Kay, A.L., Jones, R.G. (2012b). Comparison of the use of alternative UKCP09 products for modelling the impacts of climate change on flood frequency. Climatic Change, 114(2), 211-230.

McSweeney, C.F., Jones, R.G. (2013). No consensus on consensus: The challenge of finding a universal approach to measuring and mapping ensemble consistency in GCM projections. Climatic Change, 119, 617-629.

Prudhomme, C., Dadson, S., Morris, D. et al. (2012). Future Flows Climate: an ensemble of 1-km climate change projections for hydrological application in Great Britain. Earth System Science Data, 4, 143-148.

Smith, A., Bates, P., Freer, J., Wetterhall, F. (2014). Investigating the application of climate models in flood projection across the UK. Hydrological Processes, 28, 2810-2823.

Spencer, M., Essery, R., Chambers, L., Hogg, S. (2014). The Historical Snow Survey of Great Britain: Digitised Data for Scotland, Scottish Geographical Journal, 130, 252-265. 